\title{
SIMILARITIES IN TIME-SERIES OF HOUSING PRICES ON LOCAL MARKETS IN POLAND ${ }^{1}$
}

\author{
Mirosław Belej, PhD \\ Faculty of Geodesy and Land Management \\ University of Warmia and Mazury in Olsztyn \\ e-mail: caprio@uwm.edu.pl \\ Sławomir Kulesza, PhD \\ Faculty of Mathematics and Informatics \\ University of Warmia and Mazury in Olsztyn \\ e-mail:kulesza@matman.uwm.edu.pl
}

\begin{abstract}
This study examined similarities between local real estate markets in Poland from 2006 - 2013 by analyzing changes in housing prices. The analyses covered five cities - all of which are major centers of their regions: Warsaw (Mazovia - the center of Poland), Bialystok (Podlasie - the east of Poland), Cracow (Malopolska - the south of Poland), Poznan (Wielkopolska - the west of Poland) and Gdansk (Pomerania - the north of Poland).

The time period was chosen so that it covered an interval of rapid changes in real estate prices (a housing bubble) and their subsequent relaxation to the equilibrium state. Firstly, a multi-dimensional analysis which took into account the Chebyshev distance was employed. This helped to conduct an analysis of the correlation of price changes over time, which revealed their concurrence and, moreover, showed specific propagation delays to external stimuli, and hence could be a measure of the market's inertia. The degree of integration of the local markets under study changed only slightly over time; therefore, a thesis can be put forth in regard to the interrelation of local real estate markets, imagined as a system of communicating vessels. In the second stage, the damped harmonic oscillator model was employed to describe the observed evolution of real estate prices. This study exhibited high inertia in real estate markets, manifested during rapid structural changes in the system's state occurring in conditions far from equilibrium. In long-term evolution, the pace of change is slow enough for the systems to remain close to equilibrium.
\end{abstract}

Key words: housing, similarity, real estate market.

JEL Classification: C51, R30, R32.

Citation: Belej M., Kulesza S., 2014, Similarities in time-series of housing prices on local markets in Poland, Real Estate Management and Valuation, vol. 22, no. 3, s. 45-53.

DOI: $10.2478 /$ remav-2014-0026

\section{Introduction}

A real estate market is a special type of market with its own rules, and far from the definition given by mainstream economics (BRZEZICKA, WISNIEWSKI 2013). An assessment of the development of a real estate market shows that it meets the criteria of an open market, i.e. it can exchange signals with other systems, while remaining a dynamic system. Dynamic systems are mathematical models of

1 This work was supported by a grant from the National Science Centre (NCN) number DEC 2012/07/B/Hs4/03267 
phenomena which are described by equations depending on time. Such equations reflect mathematical relationships and the mutual effect of different variables on the system's behavior.

In a physical sense, such equations usually appear as a consequence of applying some conservation laws of a general nature (e.g. conservation of mass, momentum etc.) to specific problems. Considering the complexity of processes, building-up a dynamic model usually requires considering the influence of only the most significant factors (the Pareto principle), disregarding the influence of less important ones. These methods may be extended to: biology, transport, economics, the real estate market and others. There are two methods of describing such phenomena: the phenomenological approach, in which state variables in a model are numerically fitted to the experimental data, and the $\boldsymbol{a b}$ initio approach, which focuses on seeking the fundamental laws of behavior which govern a system's evolution. Each of these methods has its pros and cons: the first one allows a model to be fitted to the empirical data without going into the real mechanisms behind the system, whereas the second one focuses on the causes of the system behavior rather than numerical accuracy.

In order to analyze a dynamic system such as a real estate market, one should focus on the fact that it changes over time by switching from one equilibrium state to another. According to DOMAŃSKI (2008), if the development of a system is understood to mean its movement towards a state of equilibrium, then even if the system remains in a state close to equilibrium, it undergoes small changes and stronger impulses make it grow and develop. The process of development not only results in an increase in its size, but its structure also changes and periods of structural changes intertwine with periods of evolutionary changes.

Such structural changes and gradual changes have also been observed in different local markets in Poland. During the period 2006-2013 both types of changes occurred, i.e. structural (changes in the hierarchical system of local markets), which resulted in a rapid increase in real estate prices, and gradual changes, which resulted in a steady decrease in real estate prices (system relaxation).

The similarity of local housing real estate markets has been the subject of several studies. For example, the similarity between different regions has been analyzed by BAJEROWSKI and BIŁOZOR (2005) with scale-free networks. KAŁKOWSKI (2003) and BELNIAK (2001) analyzed a range of issues regarding local market dynamics. MCPEAKE (1998) examined the relationship between religion and choices made by buyers on local real estate markets in Belfast, whereas TROJANEK (2008) developed real estate price indexes on local markets, and KRAJEWSKA (2013) analyzed various real estate markets in terms of a real estate appraiser's responsibilities. Determinants of the development of local housing real estate markets have been examined by FORYŚ (2011) with Hellwing's parametric method, whereas SCANLON and WHITEHEAD (2011) conducted an analysis on pricing factors and macroeconomic influences. House price dynamics and the flexibility of mortgage contract terms have been examined by CAMPBELL and COCCO (2003), with the consequences of mortgage credit expansion looked into by MIAN and SUFI (2009). In order to identify a homogeneous group of housing real estate markets, BELNIAK AND GŁUSZAK (2011) applied multi-dimensional methods, cluster analysis and principal component analysis. DiTTMANN $(2012,2013)$ examined the phenomenon of convergence and divergence on local markets as well as similarities in terms of offer and transaction prices, while HECKMAN (2008) examined the possibility of using a non-linear causality in multivariable fractional polynomials (MFPs).

This study examined the processes taking place in local markets in terms of structural and evolutionary changes, taking into account changes in the prices of housing real estate in five selected cities of Poland regarded as the major centers of their regions: Warsaw (Mazovia - central Poland), Bialystok (Podlasie - eastern Poland), Cracow (Malopolska - southern Poland), Poznan (Wielkopolska western Poland) and Gdansk (Pomerania - northern Poland). The first stage of the study employed multi-dimensional analysis and the second employed the damped harmonic oscillator model.

\section{Subject and scope of the study}

In order to examine how local real estate markets behave in terms of structural and evolutionary changes, as well as to confirm the presence of temporal analogies of price variability and the concurrence of local real estate markets, five Polish cities, regarded as major centers in their regions, were selected for detailed analyses: Warsaw (Mazovia - central Poland), Bialystok (Podlasie - eastern Poland), Cracow (Malopolska - southern Poland), Poznan (Wielkopolska - western Poland) and Gdansk (Pomerania - northern Poland). Table 1 shows the main statistical data for the selected local markets. 
Main statistical data

\begin{tabular}{|c|c|c|c|c|}
\hline Town & Province & $\begin{array}{c}\text { Area } \\
{\left[\mathrm{km}^{2}\right]}\end{array}$ & Population & $\begin{array}{c}\text { Population density } \\
\left.\text { people } / \mathbf{k m}^{2}\right]\end{array}$ \\
\hline Warsaw & Mazowieckie & 517 & $1,715,517$ & 3,317 \\
\hline Cracow & Malopolskie & 327 & 758,463 & 2,321 \\
\hline Poznan & Wielkopolskie & 262 & 550,742 & 2,103 \\
\hline Gdansk & Pomorskie & 262 & 460,427 & 1,758 \\
\hline Bialystok & Podlaskie & 102 & 294,921 & 2,888 \\
\hline
\end{tabular}

Source: central Statistical Office (data as of 26.02.2013).

The average prices of $1 \mathrm{~m}^{2}$ of secondary market residential real estate between Q3 2006 and Q1 2013 were used in the study. The data were taken from the Residential Real Estate Price Database, maintained by the National Bank of Poland, and are presented in Fig. 1.

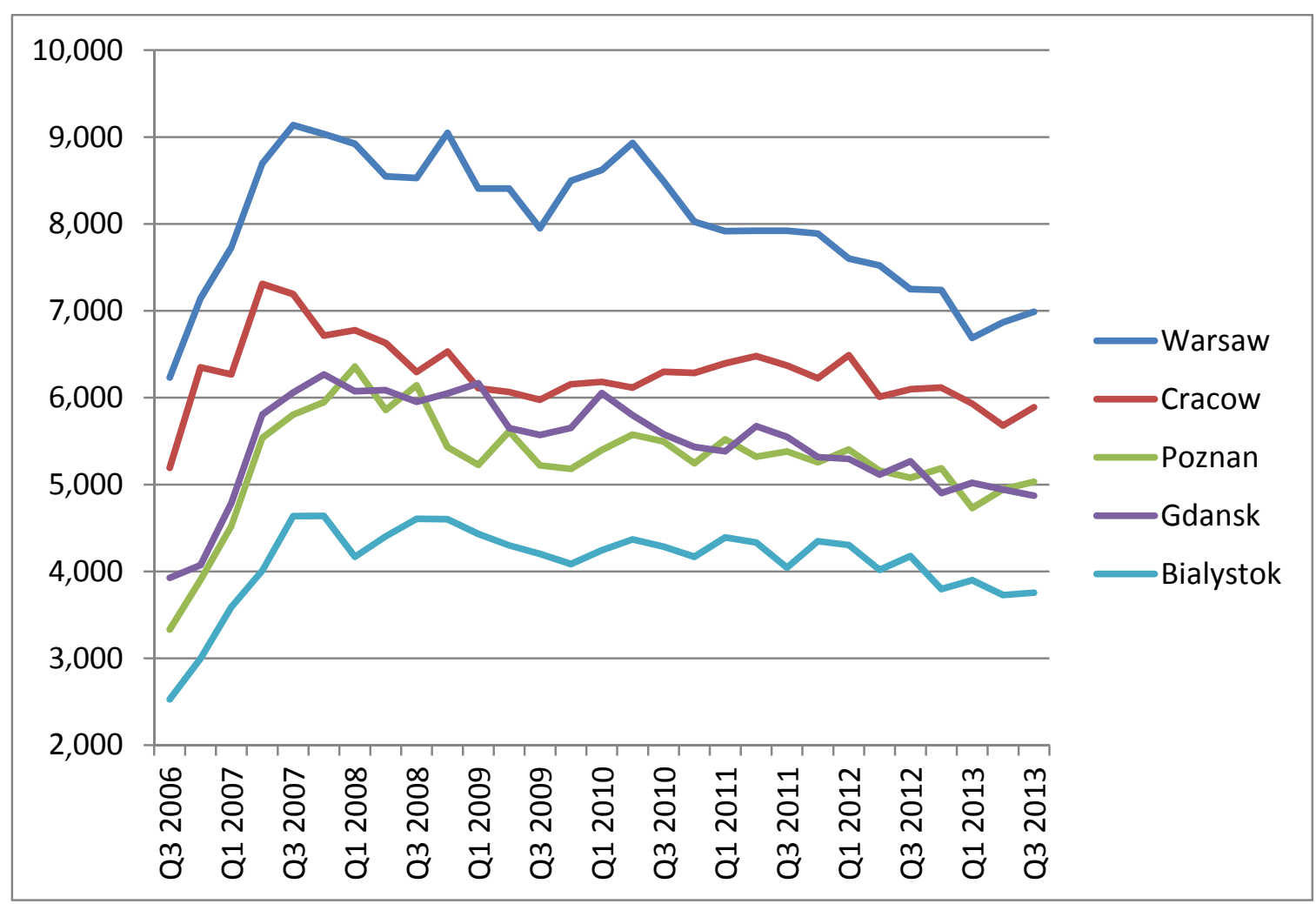

Fig. 1. Diversity of prices of $1 \mathrm{~m}^{2}$ of secondary market residential real estate in selected cities of Poland during the period from 2006-2013. Source: own study based on NBP data.

It may be claimed that the position occupied by each of the analyzed cities in the ranking in terms of real estate prices is a direct consequence of a set of attributes which characterize the town, i.e. its size, economic and administrative significance, demographic factors, attractiveness to investors, population, wealth and unemployment rate. Traditionally, the highest real estate prices $(\max .9,137$ $\left.P L N / m^{2}\right)$ are observed in Warsaw. They are followed by Cracow (max. 7,309 PLN/m²), Poznan (max. 6,357 PLN $\left./ \mathrm{m}^{2}\right)$ and Gdansk $\left(\max .6,267 \mathrm{PLN} / \mathrm{m}^{2}\right)$, which hold mid-rank positions among the most expensive cities in Poland. Bialystok comes last, with real estate prices nearly twice lower than those in Warsaw (max. 4,637 PLN/m²).

Considering only the price level, these are, indeed, different local markets, but a graphic interpretation shows a high level of proportionality of dynamics and trends in residential real estate price changes on selected local markets. Regardless of the starting level of real estate prices in Q3 2006, each of the local markets responded in the same way to the changes in their market environment and 
underwent similar changes in temporal and value aspects. Two special periods can be distinguished in the behavior of the markets;

- period I - market instability - from Q3 2006 to Q4 2007,

- period II - market stability - from Q1 2008 to Q3 2013.

An analysis of price variability on local markets during the period between 2006 and 2013 (Fig. 1) reveals some disturbance of well-established relationships between these markets, such as:

- variable dynamics of real estate prices are observed - rapid increases during the period of instability and steady decreases during the period of stability,

- different levels of price diversification are observed - the highest (4,753 PLN/m²) in Q1 2008 and the lowest $\left(2,788 \mathrm{PLN} / \mathrm{m}^{2}\right)$ in Q1 2013,

- there are changes in the hierarchy tree - during the period of instability, the behavior of the market was fully proportionate, whereas during the period of steady decreases, the distance between the price levels changed significantly resulting in changes in the classification of the cities.

A nearly uniform response of all the local markets during period I indicates that local factors were not the reason for the rapid increases in the real estate prices in 2006-2007; they only helped to establish the position in the hierarchy of the local markets. Some turbulence of the trajectory is clearly seen in period II, which generated changes in the hierarchy of the local markets.

\section{An analysis of structural changes of local markets}

To illustrate the variability of the structure of the hierarchy of individual local markets, which developed depending on the dynamics of residential real estate prices in 2006-2013, a multidimensional analysis - cluster analysis - was applied, taking into account the Chebyshev distance. The algorithm employed in the analysis develops a hierarchy of classifications for a set of objects (successive clusters), beginning with a division in which each object makes up an individual cluster, and ending with a division in which all the objects belong to one cluster.

In order to show the hierarchical relationship and similarities between the local markets in question, they were grouped into two periods defined earlier, i.e. during the period of instability (Q3 2006 - Q4 2007) and during the period of stabilization of the real estate market (Q1 2008 - Q3 2013). Chebyshev distances, mean values and standard deviations for Warsaw, Cracow, Poznan, Gdansk and Bialystok are shown in Table 2.

Table 2

Chebyshev distances, mean values and standard deviations for period I and II in cluster analysis for selected local markets

\begin{tabular}{|c|c|c|c|c|c|c|c|}
\hline \multicolumn{8}{|c|}{ Period I - Q3 2006 - Q4 2007} \\
\hline & Warsaw & Cracow & Poznan & Gdansk & Bialystok & Mean & $\begin{array}{l}\text { Standard } \\
\text { deviation }\end{array}$ \\
\hline Warsaw & 0 & 2,319 & 3,332 & 3,078 & 4,687 & $7,995.33$ & 1,164 \\
\hline Cracow & 2,319 & 0 & 2,446 & 2,277 & 3,351 & $6,504.33$ & 770 \\
\hline Poznan & 3,332 & 2,446 & 0 & 594 & 1,529 & $4,841.36$ & 1,086 \\
\hline Gdansk & 3,078 & 2,277 & 594 & 0 & 1,797 & $5,152.83$ & 1,029 \\
\hline Bialystok & 4,687 & 3,351 & 1,529 & 1,797 & 0 & $3,733.00$ & 862 \\
\hline \multicolumn{8}{|c|}{ Period II - Q1 2008 - Q3 2013} \\
\hline & Warsaw & Cracow & Poznan & Gdansk & Bialystok & Mean & $\begin{array}{l}\text { Standard } \\
\text { deviation }\end{array}$ \\
\hline Warsaw & 0 & 2,818 & 3,616 & 3,135 & 4,753 & $8,007.01$ & 681 \\
\hline Cracow & 2,818 & 0 & 1,201 & 1,213 & 2,609 & $6,221.30$ & 257 \\
\hline Poznan & 3,616 & 1,201 & 0 & 940 & 2,189 & $5,380.58$ & 365 \\
\hline Gdansk & 3,135 & 1,213 & 940 & 0 & 1,906 & $5,538.89$ & 408 \\
\hline Bialystok & 4,753 & 2,609 & 2,189 & 1,906 & 0 & $4,202.61$ & 243 \\
\hline
\end{tabular}

Source: own elaboration.

The results of the multi-dimensional analysis have been presented graphically as two hierarchical trees, i.e a dendrogram, in Fig. 2.

During Period I, the traditional hierarchy of local markets was upset, which resulted in Cracow coming close to Warsaw, which was usually distanced from the other markets. It seems that such 
behavior can be explained by the structural instability of both of the markets. The other markets, i.e. Gdansk and Poznan, make up a group of similar objects, which is sometimes joined by Bialystok.

There were steady decreases in real estate prices during period II and the markets strove to restore the traditional hierarchical system, in which Warsaw was in a group separate from any of the other local markets, whereas Cracow formed a group with Poznan and Gdansk. The temporal constant of the restoration, i.e. the time constant of prices returning to a level of equilibrium (the disappearance of the "bump"), can be estimated by means of the damped oscillator mentioned above

\section{Price relaxation on local markets}

In order to illustrate the evolutionary changes on individual local markets, a harmonic oscillator model was employed, which is one of the simplest and the most common dynamic systems in physics. The oscillator equations can be successfully applied to describe the behavior of a mass attached to a stretched spring, a pendulum or oscillating electrical circuits. An important feature of a harmonic oscillator is that many interesting parameters of a system's evolution can be calculated with precision.
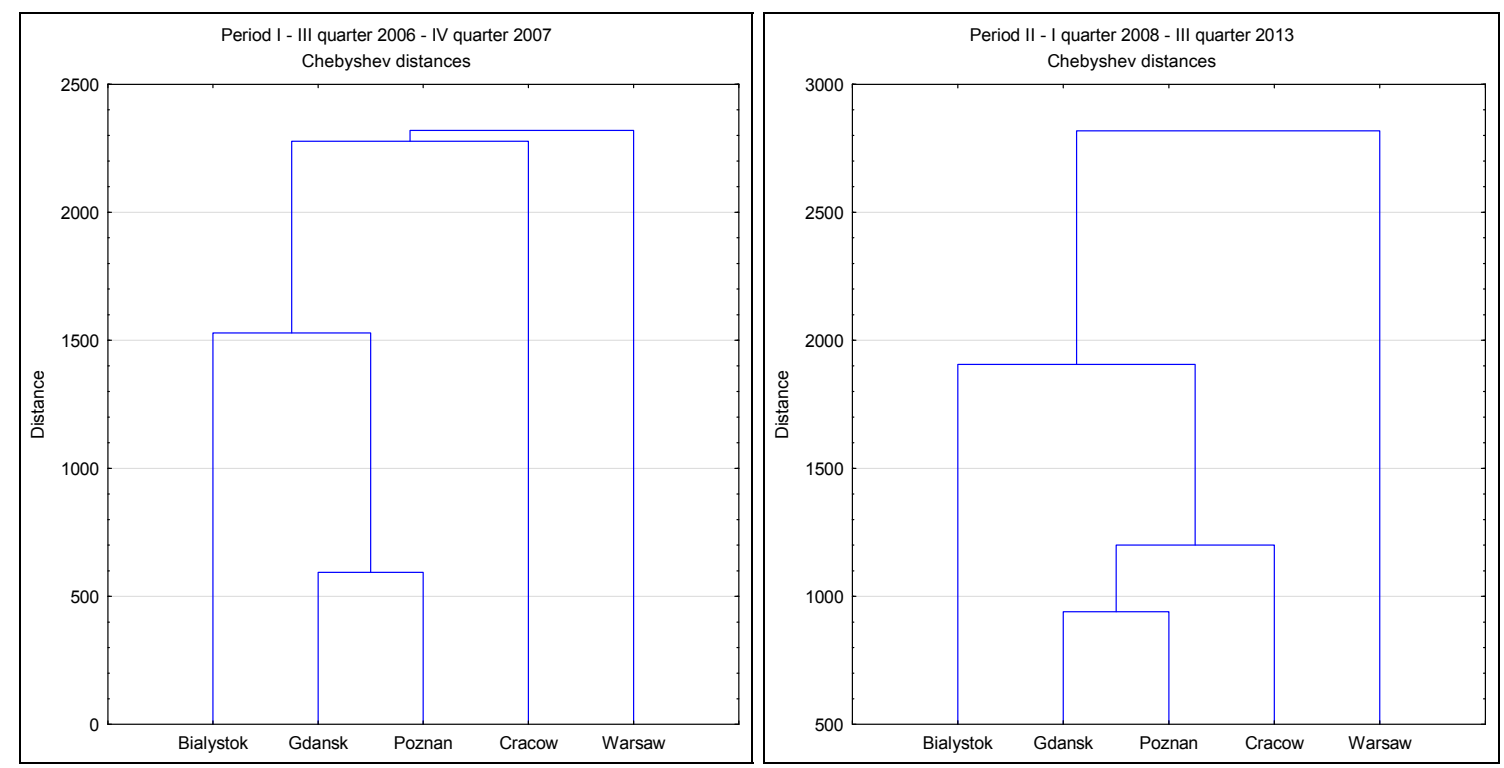

Fig. 2. Tree diagrams in the cluster analyses for Period I and Period II. Source: own elaboration.

A model of a harmonic oscillator, limited to the case of an unforced damped harmonic oscillator, has been adapted to describe the evolution of real estate prices. Such an oscillator is described by a second order ordinary differential equation:

$$
\ddot{y}+\frac{b}{m} \dot{y}+\frac{k}{m} y=0
$$

where: $\mathrm{y}$ - the position of the oscillator at time $\mathrm{t}, \ddot{y}$-the second derivative of its position after the time (acceleration), $\dot{y}$ - the first derivative (velocity), $\mathrm{b}$ - the parameter of damping (force of resistance), $\mathrm{k}-$ elastic constant, which creates a negative feedback force, and $\mathrm{m}$ - mass of the oscillator, which represents the system inertia. Knowing these values, one can introduce certain generalized parameters to the system, i.e.:

- natural frequency (of undamped vibrations): $\omega_{0}^{2}=\frac{k}{m^{\prime}}$

- relaxation time: $\tau=\frac{2 m}{b}$,

- frequency of damped oscillations: $\omega^{2}=\omega_{0}^{2}-\tau^{-2}$.

The equation of the oscillator evolution can then be shown as follows:

$$
\ddot{y}+\frac{2}{\tau} \dot{y}+\omega_{0}^{2} y=0
$$


Depending on the values of parameters $k, m$ and $b$, the system can evolve according one of three main scenarios (presented in diagrams in Fig. 3). The empirical data were fit into the model of a critically damped oscillator, the equation of which has the following form:

$$
y(t)=\left[A\left(t-t_{0}\right)+B\right] e^{-\frac{\left(t-t_{0}\right)}{\tau}}
$$

where: A and B are constant values calculated from the starting points, and $t_{0}$ is the time of delay. A characteristic feature of a critically damped system is the shortest time of returning to a state of equilibrium (relaxation time) without oscillations.

The parameters introduced in equations (2) and (3), i.e. time of relaxation and time of delay, have a strict physical meaning. The time of relaxation is defined as the time after which the dependent variable decreases from the maximum value $\mathrm{y}_{\max }$ to $\mathrm{e}^{-1} \mathrm{ymax} \approx 0.368 \mathrm{ymax}$. The longer the time, the slower the changes of the system state, described by the function of exponential decay (a specific case of an exponential function). The converse of the time of relaxation is also a measure of the system inertia, i.e. its susceptibility to fluctuations of independent variables. On the other hand, the time of delay takes accounts for the fact that the moment when the observation of the evolution of a system starts is chosen on the time axis more or less randomly. Since time flows continuously and the evolution of a system takes place regardless of whether it is or is not observed, the starting point of observation cannot be taken as the absolute beginning of the evolution. In other words, the time of delay $t_{0}$ defines the shift of the time series along the time axis, and the positive values of $t_{0}$ denote a delay relative to a conventional beginning of the observation, while negative values denote acceleration. Similar information is provided by correlation analysis. A linear correlation $R_{12}$ of two courses $\mathrm{y}_{1}(\mathrm{t})$ and $\mathrm{y}_{2}(\mathrm{t})$ is defined as the function:

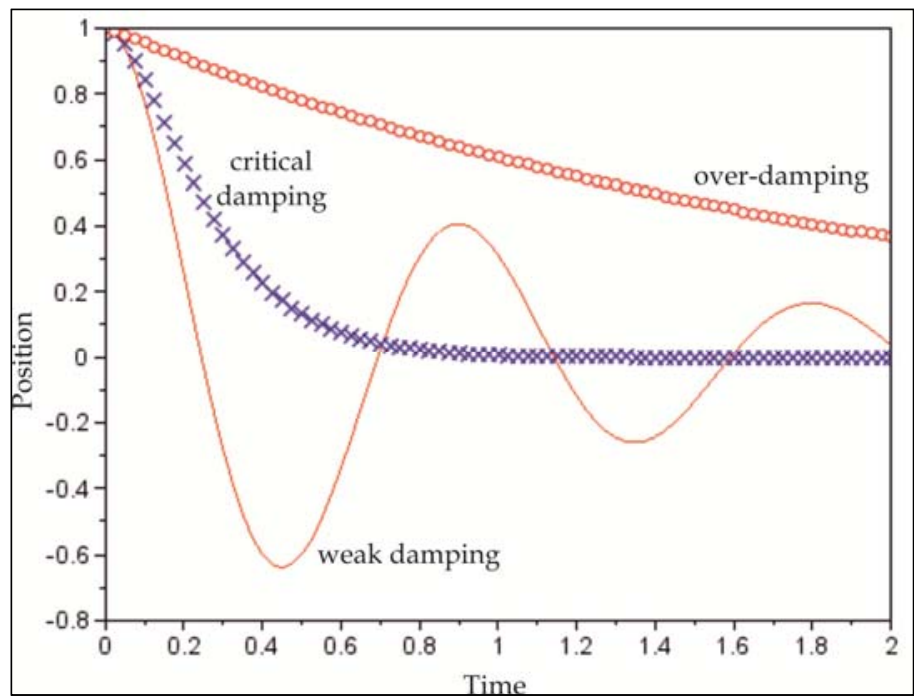

Fig. 3. Possible scenarios of evolution of a damped harmonic oscillator in the cases of: (a) weak damping (red line), (b) critical damping (blue crosses), and (c) over-damping (red points). Source: own elaboration.

$$
R_{12}\left(t_{0}\right)=\frac{\left\langle\left(y_{1}(t)-\left\langle y_{1}\right\rangle\right) \cdot\left(y_{2}\left(t-t_{0}\right)-\left\langle y_{2}\right\rangle\right)\right\rangle}{\sigma^{2}}
$$

where: $t_{0}$ - a time shift between the time series ( $\mathrm{y}_{1}$ is regarded as reference), $\sigma^{2}-$ a normalizing factor, and $<>-$ a symbol which denotes the arithmetic average of the expression. Again, if the normalized function $R_{12}$ reaches its maximum for $t_{0}<0$, it means that the examined time series is delayed relative to the reference one, while if $\mathrm{t}_{0}>0$, the series is accelerated.

The aim of the calculations and analyses presented further in the work is to verify the following hypotheses:

1) Real estate markets are dynamic systems with high inertia relative to other economic systems (e.g. stock exchange), which means that they react much more slowly to changes in external conditions.

2) The inertia of real estate becomes manifest during periods of rapid changes, when they undergo 
deep structural transformations within a short time, whereas the pace of changes of their state during long-term evolution is slow enough to ensure a state of system equilibrium.

3) The similarity of the time series in terms of the time of relaxation is concurrent with hierarchy groups which result from the cluster analysis.

4) Since delays in the time series relative to each other allow for the identification of the Warsaw local real estate market as the initiator of changes and suggest the existence of couplings between markets, they support the view of local markets as a network of communicating vessels.

The cases analyzed later on in the work continue to apply the model of a critically damped oscillator due to the shortest time taken to return to a state of equilibrium. On the other hand, the analysis completely disregards the impact of an external exciting force, and it is assumed that the system transition between states of equilibrium is caused by fluctuations of the potential barrier which separates the two states. In this sense, the analyzed real estate market is an open system and, as a consequence, its evolution is affected not only by endogenous factors (the specific nature of the market itself), but also by exogenous ones (especially the links with other markets).

Fig. 4 shows the result of fitting the critically damped oscillator model to data from the Warsaw and Cracow markets. For the first model, $\mathrm{R}^{2}$ is equal to 0.81 , which means that the model parameters fit the empirical data well, whereas for the second model it is 0.65 which, in turn, indicates poorer fitting. Such calculations have been made for all the other local markets with the results listed in Table 3.
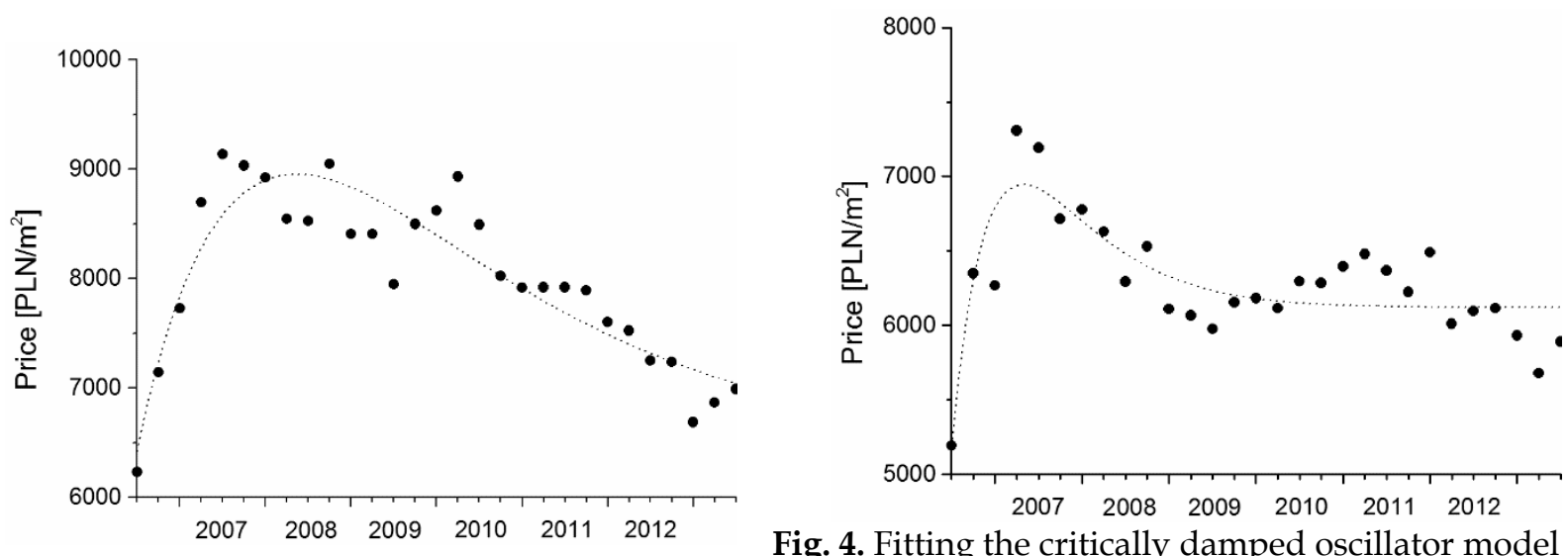

(dotted line) to data from the real estate markets (da own elaboration.

Table 3

Results of the numerical fitting of a model of a critically damped harmonic oscillator to empirical data

\begin{tabular}{cccccc|}
\hline & Warsaw & Cracow & Poznan & Gdansk & Bialystok \\
\hline $\mathbf{R}^{\mathbf{2}}$ & 0.81 & 0.65 & 0.81 & 0.86 & 0.82 \\
\hline $\begin{array}{c}\text { Relaxation time } \\
\text { (quarters) }\end{array}$ & 7.4 & 2.5 & 4.2 & 6 & 5 \\
\hline Delay (quarters) & 2 & 3 & 3.6 & 2.6 & 3 \\
\hline
\end{tabular}

Source: own elaboration.

It is a common feature of all the analyzed markets that the time of relaxation is long and ranges from about half a year (Cracow) to nearly two years (Warsaw). This testifies to the high inertia of real estate markets and to the fact that they adapt slowly to the changes in the macroeconomic sphere. Significant differences in how fast the state of equilibrium is achieved may result from specific factors which affect each of the markets: the amount of invested capital, liquidity, number of investment projects, unemployment rate, etc.

Equally interesting are the results with regard to a delay in the evolutionary leap. Their similar values, ranging from half a year (Warsaw) to nearly a year (Poznan), are a sign of the high proportionality of price changes. They also point to the Warsaw market as the initiator of changes, 
which subsequently spread through link networks, which suggests that local markets may be regarded as systems of communicating vessels.

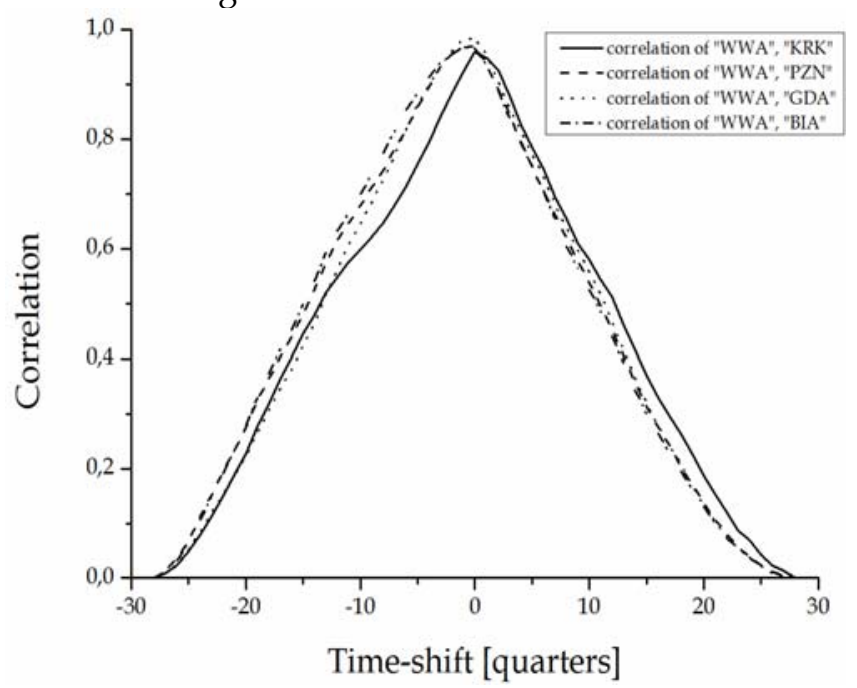

Fig. 5. Normalized coefficients of price correlation on local real estate markets with the prices of the Warsaw market. Source: prepared by the authors.

This thesis may be corroborated by the results of calculations of normalized price correlation on local markets relative to the Warsaw market, which are shown in Fig. 5. In none of the analyzed cases was the delay time longer than half a year, which is another indication of the high proportionality of the prices.

The values of the fitting index $\mathrm{R}^{2}$, which exceed 0.8 , are also a sign of good conformity of the model and empirical data. The only exception is the Cracow market, for which a much poorer fitting of 0.65 was achieved. However, a closer look at the data presented in Fig. 4 shows the existence of diminishing oscillations, which suggests the inadequacy of the assumption of critical damping of the market, and instead, the need to fit the data to a weakly damped oscillator. As a consequence of this, the Cracow market can be regarded as a vibrating market, which conforms to the results of the cluster analysis. The reasons for such deviations should probably be sought in the specific nature of the Cracow market (high potential for development being a consequence of the fact that it is well-known in Europe, and that it is similar to Warsaw in terms of local parameters).

\section{Conclusions}

The study covered the degree of integration of local real estate markets in Poland, in the period from 2006 to 2013, in five Polish cities regarded as the leading centers in their regions, i.e.: Warsaw, Bialystok, Cracow, Poznan and Gdansk. Whatever the initial level of real estate prices, each of the local markets responded to the changes in the market environment in a very similar way and underwent similar changes in terms of time and value. Based on the results of the cluster analysis and the division of the study period into two periods (market instability and stability), one may claim that Cracow is the most susceptible to changes from external factors. Depending on the changes in the market environment, it undergoes considerable vibrations, which move it towards the dominant market (Warsaw) during a period of instability. By employing a critically damped oscillator model in the study, it has been shown that the real estate markets are highly inert. This can be seen during periods of rapid changes, when they quickly undergo deep structural transformations, although the pace of changes during long-term evolution is slow enough to keep the systems close to the state of equilibrium. The delay in the time series relative to each other indicates the dominant role of the Warsaw market as the initiator of changes and suggests the existence of links between markets, which supports the concept of local markets as a network of communicating vessels.

\section{References}

BAJEROWSKI T., BIEOZOR A., 2005. Theory of Barabasi scale-free networks as a new tool in researching the structure and dynamics of regions. Studia Regionalia, No. 15, pp. 45-56.

BELNIAK S., GŁUSZAK M., 2011, Uwarunkowania i zróżnicowania lokalnych rynków mieszkaniowych w Polsce. Stan $i$ tendencje rozwoju rynku nieruchomości (Determinants and diversification of the local housing 
markets in Poland. Condition and trends in the development of real estate market), Zeszyty naukowe 192. Wydawnictwo Uniwersytetu Ekonomicznego w Poznaniu, Poznań.

BELNIAK, S. 2001. Rozwój rynku nieruchomości w Polsce (Real estate development in Poland), Wydawnictwo Akademii Ekonomicznej, Poznań.

BRZEZICKA J., WISNIEWSKI R., 2013, Ekonomia behawioralna a rynek nieruchomości - teoria i praktyka (Behavioural economics and real estate market - theory and practice), Psychologia ekonomiczna, No. 3, pp. 6-19.

CAMPBell J.Y., COCCO J., 2003. Household Risk Management and Optimal Mortgage Choice. Quarterly Journal of Economics 118(4), 1449-1494.

DitTMAN I., 2012, Lokalne rynki mieszkaniowe w Polsce - podobieństwo pod względem zmian cen transakcyjnych oraz dostępności mieszkań (Local housing markets in Poland - the similarity in terms of changes in transaction prices and availability of housing), Studia i Materiały Towarzystwa Naukowego Nieruchomości, vol. 20, No. 1, pp 71-90.

DiTTMANN I., 2013, Primary and secondary residential real estate markets in Poland - analogies in offer and transaction price development, Real Estate Management and Valuation, vol. 21, no. 1, pp. 39-48.

DOMAŃsKi R., 2008, Gospodarka przestrzenna (Spatial economy), Wydawnictwo Naukowe PWN, Warszawa.

FORYŚ I., 2011, Społeczno-gospodarcze determinanty rozwoju rynku mieszkaniowego w Polsce (Socio-economic determinants of the development of the housing market in Poland), Wydawnictwo Naukowe Uniwersytetu Szczecińskiego, Szczecin.

HeCKMAN J., 2008. Econometric Causality. International Statistical Review, 76(1), 1-27.

KAŁKOWSKI L, 2003, Rynek nieruchomości w Polsce (Real estate market in Poland), Wydawnictwo Twigger, Warszawa.

KRAJEWSKA M., 2013, The problem of real estate research area selection for the purpose of appraisal process, Real Estate Management and Valuation, vol. 21, no. 3, pp. 25-34.

MCPEAKE J., 1998, Religion and Residential Search Behaviour in the Belfast Urban Area, Housing Studies, Vol. 13, No. 4, pp. 527-548

MiAn A., Sufi A., 2009. The Consequences of Mortgage Credit Expansion: Evidence from the 2007 Mortgage Crisis. Quarterly Journal of Economics, 124(4), 1449-96.

SCANLON K., WHITEHEAD C., 2011. The UK mortgage market: responding to volatility. Journal of Housing and the Built Environment. 26: 277-293.

TROJANEK R., 2008, Wahania cen na rynku mieszkaniowym (Fluctuations in the housing market), Wydawnictwo Akademii Ekonomicznej, Poznań. 